\title{
Infestation of an owl (Bubo bubo) with Lucilia spp.
}

\author{
Khodadad Pirali-Kheirabadi • \\ Mehdi Cheraghchi-Bashi $\cdot$ Shahrokh Navidpour
}

Received: 17 January 2009 / Accepted: 10 March 2009/Published online: 1 April 2009

(C) The Author(s) 2009. This article is published with open access at Springerlink.com

\begin{abstract}
Myiasis is an infestation of tissue with the larval stage of dipterous flies. This condition mostly affects the skin but may also occur in certain body cavities. It can occur in either animals or humans and is caused by parasitic dipterous fly larvae feeding on the host's necrotic or living tissue. This disease rarely effects birds especially owls. In this study, infestation of an owl with cutaneous myiasis is reported. In October 2008, a wounded owl was referred by the environmental department of Chaharmahal-Bakhtiary province to the clinic of veterinary science at Shahrekord University in west central Iran. At the initial examination, clinical signs were extensive with a wound under the right wing. The wound was infested with 40 white conical maggots, 3-9 $\mathrm{mm}$ in length, which led to a diagnosis of myiasis in the owl. The maggots were carefully collected from the wound using sterile forceps and were kept in $70 \%$ ethanol and transferred to the laboratory of parasitology where the diagnosis was undertaken by the observation of posterior and anterior spiracle and cephalopharyngeal apparatus. According to key diagnostic features for mag-
\end{abstract}

K. Pirali-Kheirabadi $(\square)$

Department of Pathobiology, Faculty of Veterinary Medicine, University of Shahrekord,

Shahrekord 115, Iran

e-mail: khpirali@yahoo.com

M. Cheraghchi-Bashi

Faculty of Veterinary Medicine, University of Shahrekord,

Shahrekord, Iran

S. Navidpour

Department of Entomology,

Razi Vaccine and Serum Research Institute,

Sepah St., Hejrat Sq.,

Ahvaz, Khūzestān, Iran gots in birds, the larvae were identified as Lucilia sericata and Lucilia cuprina (Diptera: Calliphoridae). The wound was treated using usual acaricides, but due to the severity of the infestation and because of the delay in referring the animal to the clinic, it died 3 days post-treatment. This is the first report in Iran of an infestation of the Eurasian eagle owl (Bubo bubo) with L. sericata and L. cuprina (Diptera: Calliphoridae).

Keywords Owl · Myiasis · Lucilia sericata $\cdot$ Lucilia cuprina

\section{Introduction}

Owls are an order of birds of prey and are classified in the order Strigiformes in which there are over 200 extant species. Owls mostly hunt small mammals, insects, and other birds. Most are solitary and nocturnal and they are found in all regions of the world except Antarctica, most of Greenland, and some remote islands. There is little information available in the literature about the prevalence of parasitic diseases in populations of wild owls. These birds, however, are susceptible to infections and infestations by parasites even though they often do not display clinical signs. While some ectoparasites such as fleas (Nosopsyllus fasciatus, Pulex irritans), lice (Menopon and Liperus), and mites (Dermanyssus gallinarum) are commonly observed infesting birds, adult individuals of the species Cochliomyia hominivorax oviposit on fresh wounds of the host (Alexander 2006). The larvae hatch during the first $24 \mathrm{~h}$ and penetrate into wounds caused by accidents and biting. The larvae release proteolytic enzymes that digest tissues and produce extensive lesions (Alexander 2006; Soulsby 1987; Scott et al. 1996). 


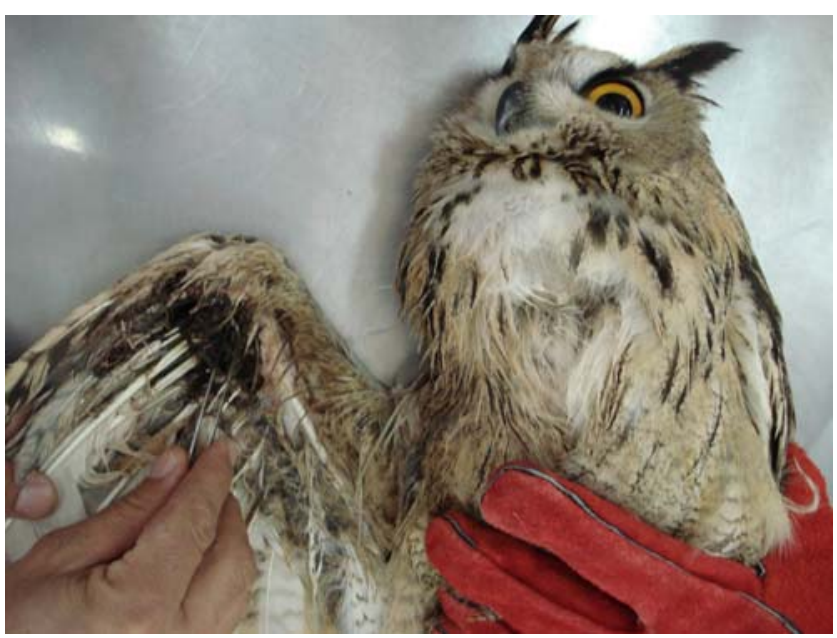

Fig. 1 Eurasian eagle owl

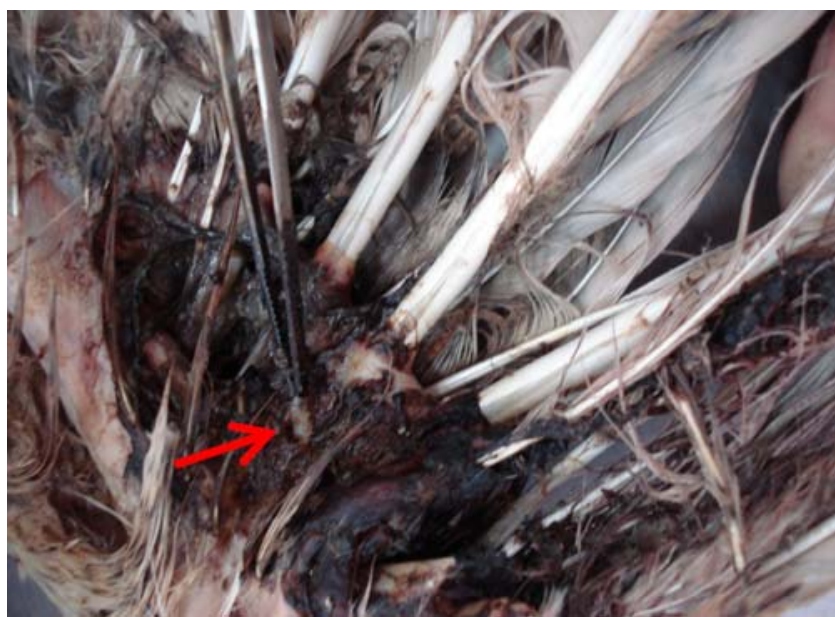

Fig. 2 Maggots in wing wound (arrow)

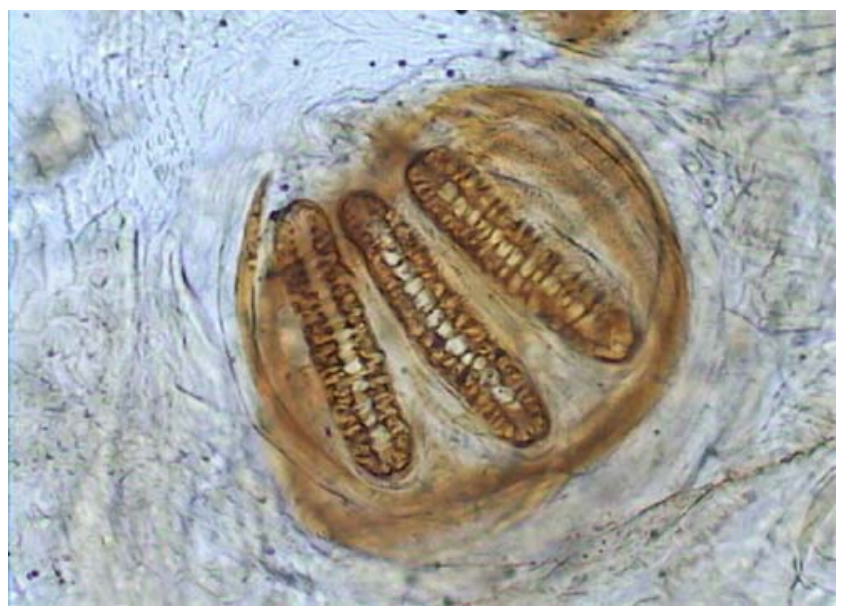

Fig. 3 Posterior spiracles of $L$. sericata

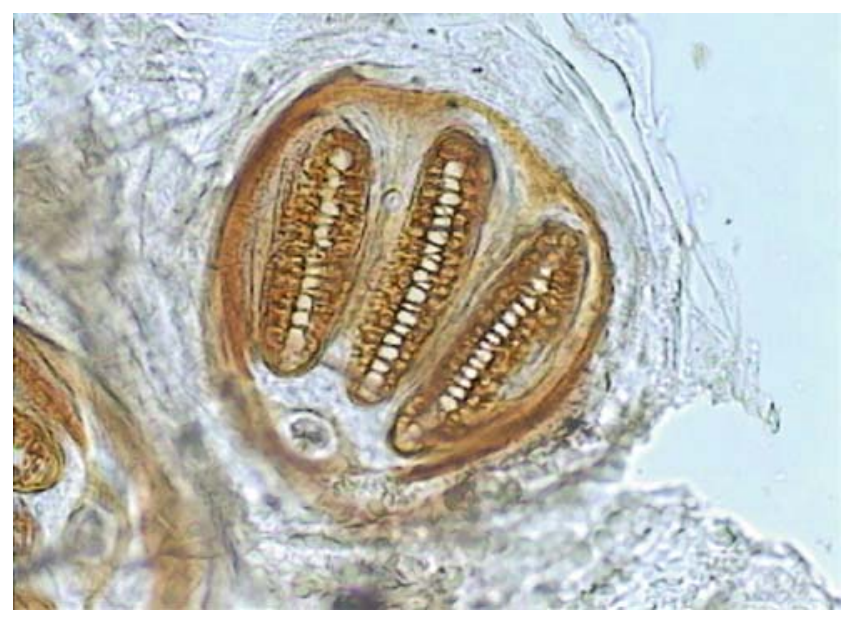

Fig. 4 Posterior spiracles of L. cuprina

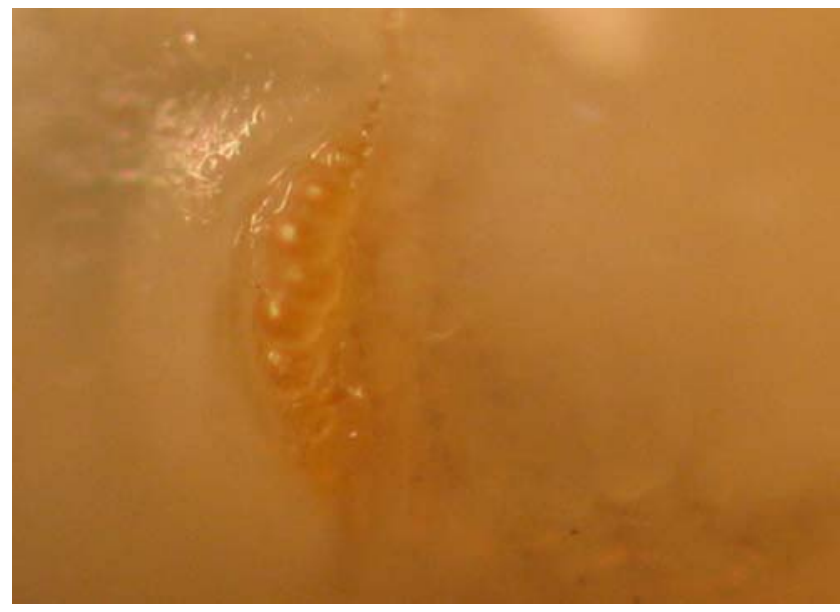

Fig. 5 Anterior spiracles of lucilia larvae

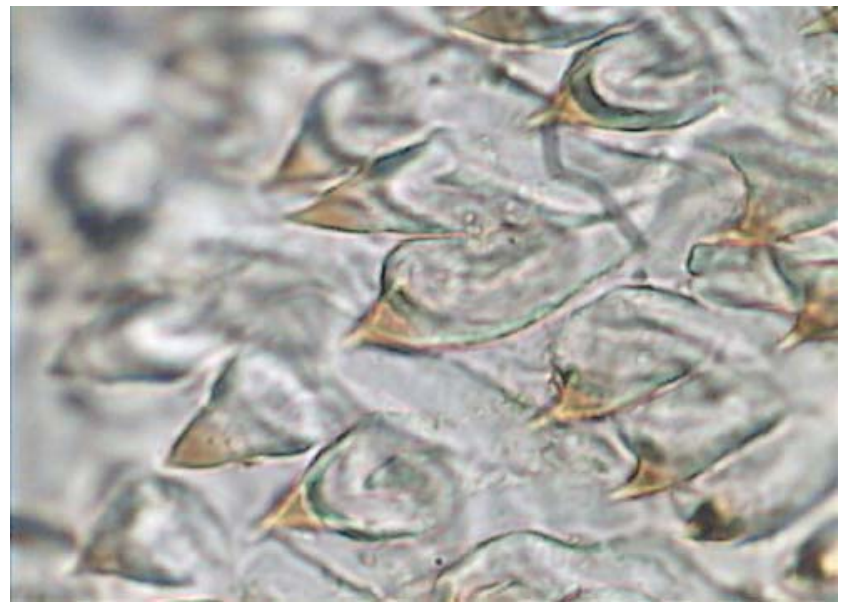

Fig. 6 Spines on the surface of larvae L. sericata 
The diagnosis of screwworm myiasis can be done easily based on the identification of the maggots. Massive infestations are common and can lead to death if not treated at the early stage (Soulsby 1987). While cases of body cavity myiasis are frequently reported in domestic animals, mainly livestock and dogs (Alexander 2006; Cramer-Ribeiro et al. 2002; Moya-Borja 2003) and in wild animals from the Tropical Americas (Moya-Borja 2003; Urquhart et al. 1990), there are few reports on the occurrence of this disease in owls. In this study, infestation with Lucilia sericata and Lucilia cuprina (Diptera: Calliphoridae) maggots is reported in an owl for the first time in Iran.

\section{Materials and methods}

A young male Eurasian eagle owl was referred to the clinic of veterinary science at Shahrekord University by the environmental department of Chaharmahal-Bakhtiary province (west central Iran) for treatment (Fig. 1). A clinical examination was performed and fly larvae were observed under the right wing of the owl (Fig. 2). The owl was treated with single-dose ivermectine $0.006 \mu \mathrm{g} / \mathrm{kg}$ (intramuscular (IM)-Ivectin ${ }^{\circledR}$; Lab. Razak Co. Ltd.) and lincomycin + spectinomycin $0.1 \mu \mathrm{g} / \mathrm{kg}$, (IM-Lincopec ${ }^{\circledR}$; Virbac Lab. Razak Co. Ltd.) as well as manual removal of the larvae followed by a local dressing. The bird was kept in the clinic; however, due to the severity of the infestation, it had to be euthanized. The larvae were collected, fixed in $70 \%$ alcohol, and observed using a stereo microscope (Olympus CX41, Japan). Based on their length, the morphology of anterior and posterior spiracles and cephalopharyngeal apparatus, the color of the maggots, and the spines on the surface of the larvae, the larvae were classified as L. sericata and L. cuprina (Diptera: Calliphoridae) (Figs. 3, 4, 5, and 6). We used the same morphological characteristics for identifying L. sericata and L. cuprina as Spradbery used in 1991 (Spradbery 1991).

\section{Results and discussion}

Owls are beneficial predators and act as a form of natural pest control-an alternative to toxic chemical pesticides and rodenticides. These predators provide us with free natural ecoservices. Like other birds, the owl is susceptible to a great variety of infectious and noninfectious disease, such as viral disease (herpesvirus), bacterial disease (dermatophilosis), and parasitic disease (Trichomonas) (Jessup 1980; Hunt 1970; McClure 1971). A rare parasitic disease in owl is infestation with diptera larva. The term myiasis was first proposed by Hope in 1840 to refer to diseases of humans originating specifically with dipterous larvae (Kirby and Spence 1815). Myiasis in birds has been reported in geese due to the gold fly species $L$. sericata and L. cuprina (Rauchbach and Hadani 1972), in duck due to Sarcophagidae (Wobeser et al. 1981), in turkey by cutaneous myiasis by $L$. sericata and L. cuprina (AlKhalidi and Shareef 1985), in finch by Muscidae (Fessl 2006), in hawk by Protocalliphora (Tirrell 1978), in nestling birds by Protocalliphora braueri larvae (Eastman et al. 1989), and in owls by Muscidae and Protocalliphora avium (Proudfoot 2006; Tirrell 1978). Data obtained from this study indicate that infestation by $L$. sericata and $L$. cuprina (Diptera: Calliphoridae) may be a rare event in the Eurasian eagle owl (Bubo bubo) in Iran as this is the first time it has been reported.

Open Access This article is distributed under the terms of the Creative Commons Attribution Noncommercial License which permits any noncommercial use, distribution, and reproduction in any medium, provided the original author(s) and source are credited.

\section{References}

Alexander JL (2006) Screwworms. J Am Vet Med Assoc 228:357367. doi:10.2460/javma.228.3.357

Al-Khalidi NW, Shareef AM (1985) Myiasis in a turkey. Avian Dis 29 (4):1235-1238. doi:10.2307/1590478

Cramer-Ribeiro BC, Sanavria A, Oliveira MQ, Souza FS, Rocco FS, Cardoso PG (2002) Inquérito sobre os casos de Miíase por Cochliomya hominivorax em gatos das zonas norte, sul e oeste e do centro do município do Rio de Janeiro no ano de 2000. Braz J Vet Res Anim Sci 39:165-170

Eastman MD, Johnson LS, Kermott LH (1989) Ectoparasitism of nestling house wrens, Troglodytes aedon, by larvae of the blow fly Protocalliphora braueri (Diptera: Calliphoridae). Can J Zool 67(10):2358-2362

Fessl B (2006) The life-cycle of Philornis downsi (Diptera: Muscidae) parasitizing Darwin's finches and its impacts on nestling survival. Parasitology 133(Pt 6):739-747

Kirby W, Spence W (1815) An introduction to entomology, vol. 1. Longman, Hurst, Rees, Orme \& Brown, London, p 512

Jessup DA (1980) Trichomoniasis in great horned owls. Mod Vet Pract 61(7):601-604

Hunt RD (1970) Morphology of a disease with features of malignant lymphoma in marmosets and owl monkeys inoculated with Herpesvirus saimiri. J Natl Cancer Inst 44(2):447465

Moya-Borja GE (2003) Erradicação ou manejo integrado das miíases neotropicais das Américas. Pesqui Vet Bras 23:131-138. doi:10.1590/S0100-736X2003000300006

McClure HM (1971) Dermatophilosis in owl monkeys. Medical Mycology 9(3):185-190

Proudfoot GA (2006) Ferruginous pygmy-owl (Glaucidium brasilianum) and eastern screech-owl (Megascopes asio) was new hosts 
for Philornis mimicola (Diptera: Muscidae) and Ornithodoros concanensis (Acari: Argasidae). J Wildl Dis 42(4):873-876

Rauchbach K, Hadani A (1972) Myiasis of the skin in the goose and dog due to the gold fly species Lucilia sericata (Meigen 1862). Dtsch Tierarztl Wochenschr 79(15):365-366

Soulsby EJL (1987) Parasitologia y Enfermidades Parasitarias en los Animales Domésticos. Interamericana, Mexico, p 823

Spradbery JP (1991) A manual for the diagnosis of the screw-worm fly. CSIRO Division of Entomology, Australia, pp 3-45. ISBN 0 643052682

Scott DW, Miller WH, Griffin CE (1996) Doenças parasitárias da Pele. In: Scott DW, Miller WH, Griffin CE (eds) Muller \& Kirk,
Dermatologia de Pequenos Animais. Saunders, Philadelphia, pp 423-427

Tirrell PB (1978) Protocalliphora avium (Diptera) myasis in great horned owls, red-tailed hawks, and Swainson's hawks in north Dokota. Raptor Res 12(1/2):21-27

Urquhart GM, Armour J, Duncan JL, Dunn AM, Jennings FW (1990) Entomologia Veterinária. In: Urquhart GM, Armour J, Duncan JL, Dunn AM, Jennings FW (eds) Parasitologia veterinaria. Guanabara Koogan, Rio de Janeiro, p 170

Wobeser G, Gajadhar A, Beyersbergen GW, Sugden LG, 4 (1981) Myiasis by Wohlfahrtia opaca (Coq.): a cause of mortality of newly hatched wild ducklings. Can Field Nat 95:471-473 